\title{
AJANKOHTAISTA
}

\section{Re-evaluating Oral Poetry: Research on the Composers' Field}

\section{Venla Sykäri}

\section{Lectio praecursoria University of Helsinki 5.2.2011}

This day, the $5^{\text {th }}$ of February, is dedicated to our national poet Johan Ludvig Runeberg who lived in the nineteenth century. The coincidence provides a suitable setting for a discussion on composition and individual creativity in verse form. In my study, I came to connect the questions of composition and individual creativity to an oral tradition, and here I wish to explore why.

At Runeberg's time, the literary forms were cast to clearly recognizable metrical moulds. The peasants in Finland, very much like people today in Crete, also cast their creative forms of self-expression in poetic meter. While preparing for this day, I wanted to refresh my memory and to find something written by Runeberg. The first book quickly at hand was a short pastoral idyll called Hanna. In this edition, what immediately drew my attention was the foreword written by Professor Hannu K. Riikonen.

In his foreword, Riikonen describes the genre, style and literary prototype for this idyllic epic poem in hexameter. He explains the thematic centers and scenes idiomatic of this genre. After describing the numerous shared elements found in this work, he evaluates Runeberg's own creative potential in the use of these shared elements as well as his individuality in this contribution.

\section{Defining the Viewpoint}

During the time of my field work, I had become convinced that the literary domain is in fact quite similar to a living, productive oral poetry tradition like the mandinádes in Crete. This piece of literary criticism reminded me of this. There is, first of all, 
the tradition. All those recurring elements typical of the specific register: the meter, other poetic conventions, the typical motifs and idiomatic expression. There are the people engaged in this tradition, who share the knowledge of the conventions that make this tradition, and who can discuss and evaluate the individual outcomes in this genre. And there is the individual rendition; the individual who with his or her personal competence and experience draws from this tradition and makes the specific unique combination.

Between the productive forms of oral and literary poetry, there are also noteworthy differences. The most evident of these is the time span between the composition, performance and reception - in the case of the short couplets, the subject of my study, these can be nearly simultaneous, when people compose extempore in a communicative situation. Another difference is the immediacy of the experience: a lot of people within a community can compose poems and perform them, and everyone has heard them. Moreover, the audience of short poems can pick up the poems they like and apply these further to their own creative speech acts.

One of the major differences that I find between the oral and literary domains, however, concerns the role of the criticism and evaluation. Inside a tradition of oral poetry, evaluation is not done by specialists, but by the same people who compose and perform. Whereas a competent outsider in a literary domain can acquire the same amount of knowledge the author has, or even much more, in oral poetry, competent and relevant criticism is hardly accessible to outsiders.

It is however the reports and evaluations of such outsiders that form the largest part of our knowledge on oral poetry.

In Crete, I was myself the outsider. I had become familiar with the Cretan tradition during a period of studies at the University of Crete in Rethymno in 1997. Later, I returned many times and conducted several longer and shorter periods of fieldwork first between the years 1999 and 2001 and again between the years 2004 and 2007. From 2001, while conducting fieldwork, I lived in a small village in the Milopotamos valley in central Crete. My fieldwork consisted of participant observation, interviews and casual conversation. With a number of key-informants, I had the possibility to discuss again and again over a period of several years. In these conversations, my objective was to catch as much as I could of the contemporary local experience. My main experience is from central Crete, the Departments of Rethimno and Iraklio, but I have conducted several field trips and interviews in the eastern and western parts of the island, as well. The data of my study might well be described as a long-term trial to contest the limits of being an outsider.

Now, why should it take so much time to grasp what an oral tradition is about? The mandinádes are short rhyming couplets which can be improvised on the spot, but they also form a store of fixed-phrase poems that can be applied to relevant contexts in speech and singing events. The meter is around thousand years old in Greece, and the end rhyme was introduced in Crete around the fifteenth century. Ever since, the couplet form has been used in Crete both in oral and literary forms of poetry, and it is overwhelmingly popular even today. Singing and dance events associated to all major festivities as well as casual get-togethers have provided the main performance 
Venla Sykäri: Re-evaluating Oral Poetry: Research on the Composers' Field

contexts. Moreover, people improvise mandinádes in their speech. A lot of people compose poems privately, and the poetic and expressive qualities of the new compositions and performances are discussed and recycled widely.

My observations of the poetic practices in Crete were plentiful over the years. However, without specifically asking people one could very well live in Crete without realizing many of those aspects of the tradition on which I focus in the present study. For me, the reason why I wanted to discuss with people was not academic in the first place though. I was generally interested in verbal creativity in communication and the short compact mandinádes seemed to fulfill just this function. Therefore, in the beginning, I thought that what was most exiting about mandinádes was the option they gave to be spontaneous in communication. Very soon, however, I came to notice that the tradition also has an option for those whose meaningful utterances need more thinking.

Personally, this combination of verbal dexterity and silent responses was not a new phenomenon to me. It reminded me of my experiences in another context, which might be more familiar than oral poetry to many more people here. During the early school years, there was always at least one pupil in the class who was verbally talented and who could tease others with witty, often mocking remarks. Although it was far from being nice to become the target for such verbal dexterity, I always admired this skill. But I was forced to realize that I was myself one of those who could not answer in kind, on the spot. However, I would go on formulating a clever answer in my mind. When I discovered my answer, it was of course too late regarding the specific situation. For me, this silent reframing of the mockery to my favor was nevertheless a significant constituent of my self-respect. Seeing in Crete how people channeled their thinking to the composition of these short poems, I also recalled this experience as a powerful argument for the role of the verbal imagination in human life. As a poor improviser, I was eager to learn more about this talent; but with experiences of the consolation provided by verbal imagination, I could also acknowledge the meaning of this creativity in those less spontaneous. Giving significance to both of these aspects led me to discern creativity in very different kinds of utterances.

\section{Words AS EvENTS}

For an outsider, it was exciting to see how much meaning people could attribute to these poems. It was also often hard to grasp the implicit contexts from which this meaning was derived. These implicit processes of personalizing and contextualizing the poems can best be illustrated with an example.

One of my regular informants was Mitsos Stavrakakis, a man in his fifties. In our first meeting in 1999, I asked him if he remembers some especially strong moments, when a poem he had composed was related to a specific situation. As such example, he referred to the following poem.

Having been imprisoned for political reasons for two years in the 1970s, he was finally released. He had walked on the street and saw a bird in a cage. This made him 
improvise the following poem:

Mon'ópios káni filakí / borí na eksiyísi, yatí t’aidóni de borí / mes' to klouví na zísi

Only the one who's been in prison / is able to explain

Why the nightingale cannot / live inside a cage

When he had recited to me this poem, I remarked to him that the metaphor of the bird in a cage is also familiar from many poems. He himself did not see this aspect of much importance - for him this extemporized poem encapsulated his very personal experience which in this poem was enlarged to concern the burden of imprisonment in general. As an outsider, I immediately thought of the similarity of the poetic metaphor in this poem with other poems, while he as an insider acknowledges the same poem as being his deeply individual expression. To me, the poem itself was just a nice poem in a chain of poems, whereas to him, this poem was an event. By choosing the expression Words as Events as the title of my study, I wished to pronounce my respect towards this insider experience.

My reaction in the above-described situation reflects very well the way the textcentered folklore research paradigm was orientated towards such compositions. Collecting a wide corpus of texts gives the possibility to analyze and categorize the textual elements shared by the individual poems. With regard to this poem, the result might be confined to the collector's note of the metaphor "a bird in the cage". There's certainly nothing wrong in noticing such metaphor; in the context of reciprocal singing, the composer would himself or herself emphasize precisely this factor. If, however, the observer limits his interest to looking only for such shared, recurrent elements, it is quite obvious that he won't catch the poet's individual processes of giving meaning to the poem.

The biases of the text-centered folklore research paradigm are well familiar to the present audience. Since the goals of this research paradigm served ideological purposes, the scholars wanted to show that the people had a long intellectual past. The present, the contemporary people and their objectives behind the poems, was rarely if ever focused on. Logically deriving from this setting, the creative processes in composition were regarded to belong to the past.

For some decades now, most researchers have applied new contextualizing and performance-centered methods of research. These new methods have given them tools to hear the multitude of voices even in the archived material. The discrepancy between my observations in Crete and the academic folklore research tradition was however still very evident. As I mentioned already, my experience showed that the individual composers and performers of the Cretan mandinádes saw the value of the poetic tradition especially in their own conscious expressive contributions. The earlier research on mandinádes had readily acknowledged this fact. For example, the anthropologist Michael Herzfeld, my opponent today, had made the performers' own processes of evaluation of meaning visible in his writings. My own research 
became focused on studying even with more detail what people can do with such short rhymed form, since this form was so often neglected or even despised in earlier research. Having done archive work myself, I also wanted to add to the folkloristic knowledge of poetry what could be obtained through discussing with performers and composers.

Because conversation was the major method of research and I had the possibility to discuss with some people recurrently, I tried to grasp the shared ideals and structures which can provide the people such an easy access to poetic imagination. A special challenge for me was to understand why people seemed to attribute so much meaning to single poems, which from my perspective did not seem to be contextualized at all. Moreover, during my fieldwork, the appearance of mobile phones introduced the mandinádes all the more to the new media.

\section{Dialogic Oral Poetry}

The negotiations of meaning during fieldwork made me conclude that this tradition is essentially a dialogic form of oral poetry. The shared, recurrent elements of the poetic language allowed the personalization and contextualization of the poems because the latter processes were always also understood as dialogic. The essential principle of conceptualizing this dialogism is the indigenous idea of theme. In a performance, each poem reflects a certain theme, a topic of speech. This topic can be a theme introduced in the interactional exchange of poems in a singing event. In these singing events, Cretan poets and performers acknowledge the meaning of the poem in its intertextual connection to other poems.

In a singing event, even an outsider can follow this concrete dialogue, but a dialogue can as well be less apparent. The dialogue can be assumed from a reference, or a dialogue can be created by inserting a topic. People, who are able to improvise, can insert a poem in an everyday conversation. Between those who know each other, a performance of a certain poem may also be a reference to another known poem or to an earlier performance of a certain poem. This explicit play with poetic references, according to my interpretation, is also a dialogue.

Finally, the poetic imagination may work with poetic images. This is where we, the outsiders, will have to recognize the tradition as the meaning-creating counterpart in a dialogue. The subject matter of these poems concerns all those aspects that people may find meaningful in their life as human beings. The conventions of the poetic register give tools to undertake a dialogue at the artistic and associative level of images. The idea of theme is therefore implicitly understood also behind a single poem. This is why the change of the media in performance changes little of the traditional context as such.

At best, a composer can react to a concrete dialogic with a contribution which unfolds all these referential and textual dialogic principles at once. Connected to the example given earlier, and implying that the metaphor "bird in a cage" commonly expresses the need of liberty, we can take the following example. Here, one of my informants, 
Kostoula Papadoyanni, uses the same metaphor in a rhetorical way to discuss a more complex meaning. In this case, Kostoula's husband had wondered whether Kostoula felt that she was too much tied to home life, and felt being deprived of some things. Kostoula answered to him:

San to poulí mes' to klouví / esthánome kondá sou

Ma de zitó ti lefteriá / an íne makriá sou

Like a bird in a cage / I feel when I'm near you

But I do not ask for freedom / if that's far away from you

She first declared that she does indeed feel deprived of things in her present position. Then, in the next verse, she states that she prefers this situation to something that is yet much worse.

The result of observing the tradition and conversing with people for over a period of twelve years did not make me see the same things over and over again. Rather, I saw the familiar elements used in ever new ways and connections. I could see that the restrictions of the poetic meter often generate impulses of creativity, and that Cretans take full advantage of this process in their dialogues.

Sykäri, Venla 2011: Words as Events. Cretan Mantinádes in Performance and Composition. Helsinki: SKS.

\section{LITERATURE}

RIIKONEN, HANNU K. 2004: Runebergin Hanna - Cajanderin klassinen käännös. Esipuhe teoksessa J. L. Runeberg 2004: Hanna. Kolmilauluinen runoelma: VII-XXVII. Helsinki: Suomalaisen Kirjallisuuden Seura.

Filosofian tohtori Venla Sykäri on folkloristi Helsingin yliopistossa. 